\title{
Nutrition\&Metabolism
}

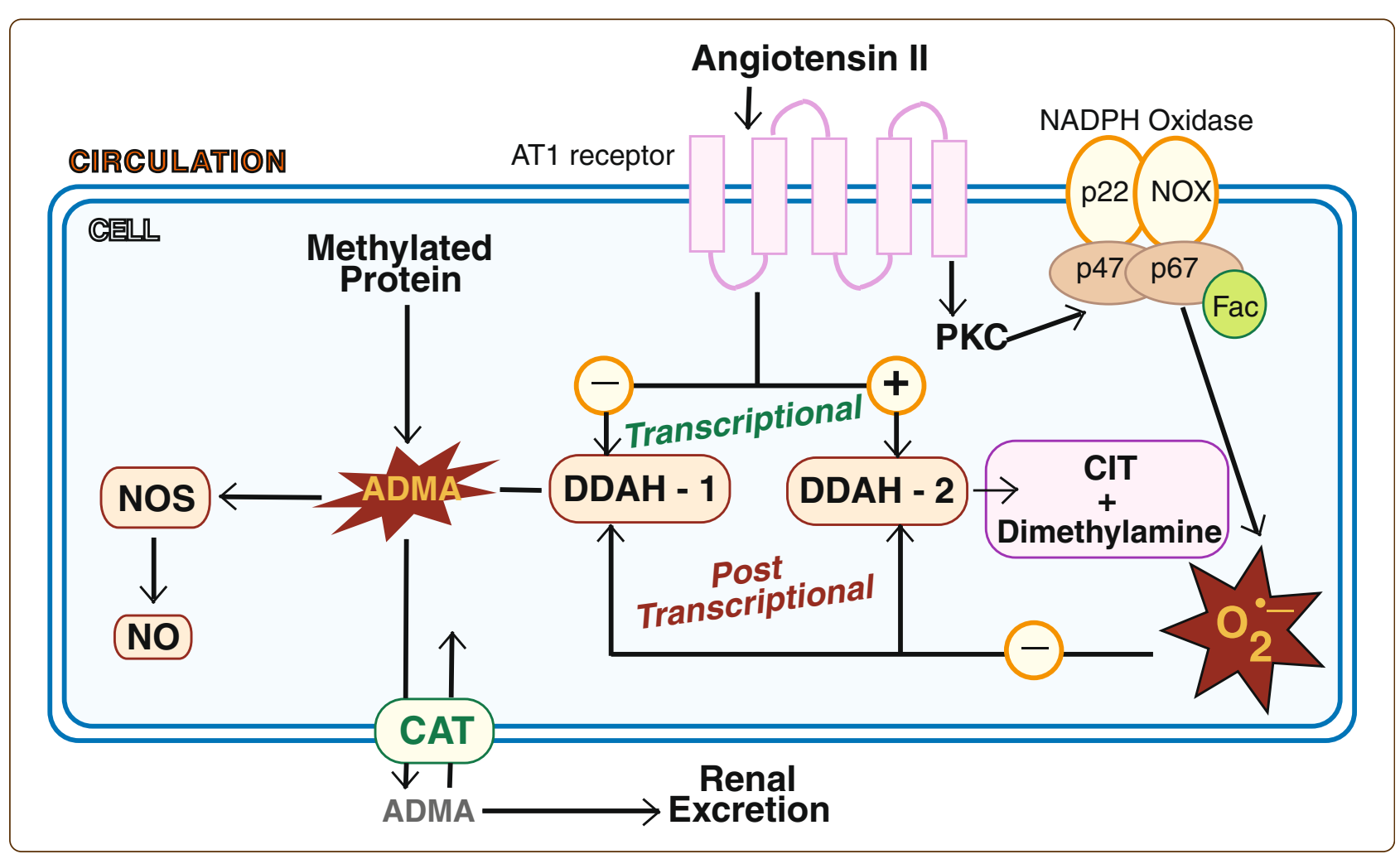

\section{AMP-activated protein kinase regulates $L$-arginine mediated cellular responses}

Mohan et al. 


\title{
AMP-activated protein kinase regulates L-arginine mediated cellular responses
}

\author{
Srinidi Mohan ${ }^{*}$, Harsh Patel $^{\dagger}$, Jorge Bolinaga ${ }^{\dagger}{ }^{\dagger}$ and Nathania Soekamto ${ }^{\dagger}$
}

\begin{abstract}
Background: Our prior study revealed the loss in short-term L-Arginine (ARG) therapeutic efficacy after continuous exposure; resulting in tolerance development, mediated by endothelial nitric oxide synthase (eNOS) down-regulation, secondary to oxidative stress and induced glucose accumulation. However, the potential factor regulating ARG cellular response is presently unknown.

Method: Human umbilical vein endothelial cells were incubated with $100 \mu \mathrm{M}$ ARG for $2 \mathrm{~h}$ in buffer (short-term or acute), or for 7 days in culture medium and challenged for $2 \mathrm{~h}$ in buffer (continuous or chronic), in the presence or absence of other agents. eNOS activity was determined by analyzing cellular nitrite/nitrate $\left(\mathrm{NO}_{2}^{-} / \mathrm{NO}_{3}^{-}\right)$, and $\mathrm{AMP}$-activated protein kinase (AMPK) activity was assayed using SAMS peptide. ${ }^{13} \mathrm{C}_{6}$ glucose was added to medium to measure glucose uptake during cellular treatments, which were determined by LC-MS/MS. Cellular glucose was identified by o-toluidine method. Superoxide $\left(\mathrm{O}_{2}^{-}\right)$was identified by EPR-spin-trap, and peroxynitrite $\left(\mathrm{ONOO}^{-}\right)$was measured by flow-cytometer using aminophenyl fluorescein dye.
\end{abstract}

Results: Short-term incubation of cells with $100 \mu \mathrm{M}$ ARG in the presence or absence of $30 \mu \mathrm{M} \mathrm{L-N}{ }^{G}$-Nitroarginine methyl ester (L-NAME) or 30 MM AMPK inhibitor (compound C, CMP-C) increased cellular oxidative stress and overall glucose accumulation with no variation in glucose transporter-1 (GLUT-1), or AMPK activity from control. The increase in total $\mathrm{NO}_{2}^{-} / \mathrm{NO}_{3}^{-}$after $2 \mathrm{~h} 100 \mu \mathrm{M}$ ARG exposure, was suppressed in cells co-incubated with $30 \mu \mathrm{M}$ CMP-C or L-NAME. Long-term exposure of ARG with or without CMP-C or L-NAME suppressed $\mathrm{NO}_{2}^{-} / \mathrm{NO}_{3}^{-}$, glucose uptake, GLUT-1, AMPK expression and activity below control, and increased overall cellular glucose, $\mathrm{O}_{2}^{--}$and $\mathrm{ONOO}^{-}$. Gluconeogenesis inhibition with $30 \mu \mathrm{M}$ 5-Chloro-2-N-2,5-dichlorobenzenesulfonamido-benzoxazole (CDB) during ARG exposure for $2 \mathrm{~h}$ maintained overall cellular glucose to control, but increased cellular glucose uptake. Continuous co-incubation with $\mathrm{CDB}$ and $\mathrm{ARG}$ increased $\mathrm{NO}_{2}^{-} / \mathrm{NO}_{3}^{-}$, glucose uptake, GLUT-1, AMPK expression and activity, and maintained overall cellular glucose, $\mathrm{O}_{2}^{--}$and $\mathrm{ONOO}^{-}$to control conditions.

Conclusion: The present study provides the fundamental evidence for AMPK as the primary modulator of ARG cellular responses and for regulating the mode of glucose accumulation during short-term and continuous ARG treatments.

Keywords: L-Arginine, AMPK, Nitric oxide, Superoxide, Peroxynitrite, Endothelial nitric oxide synthase

\section{Background}

Use of L-arginine (ARG) as a dietary supplement has gained popularity in the last decade after its role as the endogenous substrate for nitric oxide synthase was identified. In the National Institute of Health (NIH) website, "Medlineplus" [1], the use of ARG in as many as 44 diseases and diagnoses were discussed and categorized according to the strength of scientific evidence supporting its use.

\footnotetext{
*Correspondence: smohan@une.edu

${ }^{\dagger}$ Equal contributors

Department of Pharmaceutical Sciences, College of Pharmacy, University of New England, 716 Stevens Avenue, Portland, ME 04103, USA
}

In patients with stable angina pectoris, $6 \mathrm{~g}$ ARG/day for 3 days increased their exercise tolerance [2], and when supplemented with 2 food bars enriched with ARG per day for 2 weeks improved vascular function, exercise capacity and quality aspects of life [3]. In patients with congestive heart failure, $9 \mathrm{~g}$ ARG/day for 7 days prolonged exercise duration $[4,5]$. In addition, ARG has been found to improve immunity [6-8], in patients under critical care $[9,10]$ and in sickle cell disease $[11,12]$. As a supplement, ARG has been commercially endorsed by Nobel laureates, Drs. Louis Ignarro and Ferid Murad, who received their

\section{Biomed Central}


award (with Dr. Robert Furchgott), for their work on nitric oxide pharmacology in 1998. Examples of commercial products include N.O. XPLODE ${ }^{\circledR}$, NiteWorks ${ }^{\mathrm{TM}}$ and Arginine Extreme. Thus, the range of diseases that can be potentially benefited by ARG supplementation is therefore quite wide [9,12-16].

Of concern, the long-term effects of ARG supplementation have not been examined extensively. Only two well-conducted clinical studies are available, and both revealed that the short-term therapeutic benefits of ARG are not evident after long-term use. Study conducted by Wilson et al. [17] showed that ARG supplementation (3g/d) for 6 months, in 133 subjects, "did not increase nitric oxide synthesis or improve vascular reactivity", and "the expected placebo effect observed in studies of functional capacity was attenuated in the ARG-treated group". These authors characterized their findings as indications for the existence of "ARG tolerance", because beneficial effects was observed after one month of dosing. In the Vascular Interaction With Age in Myocardial Infarction (VINTAGE MI) trial [18], a total of 153 patients after MI was randomly assigned ARG (goal dose of $3 \mathrm{~g}$ tid) or matching placebos for 6 months. The results showed no improvement in vascular stiffness measurements or ejection fraction. Strikingly, 6 patients in the ARG group died during the study period versus none in the placebo group. The authors therefore concluded that ARG "may be associated with high postinfarct mortality", and stated that ARG "should not be recommended following acute myocardial infarction", contrary to the beneficial effects shown by the same regiment after one month $[4,15]$. These potential long-term deleterious effects of ARG supplementation have also been shown in animal studies [19].

The development of ARG tolerance upon chronic dosing thus represents a major hindrance for the use of this important amino acid to benefit patients. By understanding the mechanism(s) associated with ARG tolerance, the positive effects of ARG supplementation can be extended to benefit patients in whom short-term therapeutic effects have already been demonstrated. Our prior study shows that ARG tolerance in endothelial cell cultures may be mediated by eNOS down-regulation, secondary to oxidative stress and induced glucose accumulation [20]. We have shown in our prior study that continuous ARG exposure to stimulate $\mathrm{O}_{2}^{*-}$ overproduction via electron transport leak from the mitochondria, thereby triggering oxidation of tetrahydrobiopterin $\left(\mathrm{BH}_{4}\right)$ to dihydrobiopterin $\left(\mathrm{BH}_{2}\right)$ [21]. The diminished $\mathrm{BH}_{4}$-to$\mathrm{BH}_{2}$ ratio was then found to be the molecular link between oxidative stress and endothelial dysfunction during long-term ARG supplementation [21]. However the fundamental mechanistic factor that controls ARG mediated $\mathrm{O}_{2}^{*-}$ production that is responsible in initiating the downstream tolerance sparing events, still remains a puzzle.

The AMP-activated protein kinase (AMPK) [22], a protein consisting of three subunits $\alpha, \beta$, and $\gamma$, is an important energy-sensing/signaling system by which cells sense and decode changes in energy status. All three subunits are required for expression of full AMPK activity [23]. Activation of AMPK is found to be required for the decrease in glucose production and the increase in fatty acid oxidation, as well as in increasing glucose uptake in skeletal muscles. Thus, the overall effect of AMPK activation is to switch off ATP-consuming pathways such as lipogenesis or gluconeogenesis, whereas switching on ATP-producing pathways such as fatty acid and glucose oxidation. Further, an increase in AMPK activity under various physiological and pathological conditions can lead to an increase in NO synthesis by eNOS [24,25]. Conversely, eNOS knockdown mice, or shear stress [26] suppressed AMPK activity in endothelial cells, emphasizing the importance of endogenous NO in AMPK activation and subsequent metabolism of energy substrates.

The present study aims to explore the possibility of regulation on cellular AMPK activation to be fundamentally responsible in modulating the cellular responses during short-term (acute,) and continuous (chronic) ARG exposures.

\section{Methods}

\section{Supplies and reagents}

Human umbilical vein endothelial cells (HUVEC) was purchased from American Type Culture Collection (Manassas, VA) and culture reagents were from Invitrogen (Carlsbad, CA). All culture supplies and chemicals were from Laboratory Product Sales (Rochester, NY) and Sigma-Aldrich (St. Louis, MO) respectively. Commercial kits were used to examine cellular expression levels of eNOS (by Quantikine human eNOS immunoassay kit; R\&D Systems, Minneapolis, MN), AMPK (ELISA Kit by Antibiotics-Online, Atlanta, GA), glucose cellular transporter-1 (GLUT-1 ELISA kit, by My-Biosource, San Diego, CA), $\mathrm{NO}_{2}^{-} / \mathrm{NO}_{3}^{-}$(by fluorometric assay kit; Cayman Chemicals, Ann Arbor, MI), and glucose accumulation (by Quantikine glucose assay kit; Bioassay Systems, Hayward, CA). Inhibitors of eNOS (30 $\mu \mathrm{M}$ L-N ${ }^{G}$-Nitroarginine methyl ester; L-NAME), AMPK (20 mM Compound C; CMP-C), and gluconeogenesis (30 $\mu$ M 5-Chloto-2-(n-(2, 5-dichlorobenzenesulfonamide))benzoxazole; $\mathrm{CDB}$ ) were purchased from Santa Cruz Biotechnologies (Santa Cruz, CA). The internal standards for LC-MS studies, ${ }^{13} \mathrm{C}_{6}$-ARG [as ARG: $\mathrm{HCl}\left(\mathrm{U}_{-}{ }^{13} \mathrm{C}_{6}\right.$, 98\%)], $\mathrm{D}_{4}$-L-Cirulline $\left[\mathrm{D}_{4}\right.$-CIT $\left.\left(4,4,5,5-\mathrm{D}_{4}, 96.5 \%\right)\right]$, and $\mathrm{D}_{7}$-Asymmetric di-methylarginine [ADMA: $\mathrm{HCl}: \mathrm{H}_{2} \mathrm{O}$ $\left.\left(2,3,3,4,4,5,5-D_{7}, 98 \%\right)\right]$, as well as ${ }^{13} \mathrm{C}_{6}$-glucose and ${ }^{15} \mathrm{~N}_{4}$-ARG, were obtained from Cambridge Isotope 
Laboratories, Inc (Andover, MA). Deionized water $(18 \mathrm{M} \Omega$ ) was used in all experiments.

\section{Cell studies}

HUVEC were cultured in physiological F-12K medium containing $100 \mu \mathrm{M}$ ARG and $4.4 \mathrm{mM}$ glucose. For cellular uptake studies to analyze glucose influx, cells were cultured in physiological F-12K medium containing $100 \mu \mathrm{M}$ ARG, $4.3 \mathrm{mM}$ glucose and $0.1 \mathrm{mM}{ }^{13} \mathrm{C}_{6}$-glucose. All culture medium were supplemented with $20 \%$ horse serum, $100 \mathrm{U} / \mathrm{mL}$ penicillin and $100 \mu \mathrm{g} / \mathrm{mL}$ streptomycin. Cells were maintained in a humidified chamber at $37^{\circ} \mathrm{C}$ with $5 \% \mathrm{CO}_{2}$, and passages between 6 and 14 (mean passage number $=9 \pm 3$ ) were used in all the experiments. For acute studies, cell culture in 6-well plates were incubated in Locke's buffer $(154 \mathrm{mM} \mathrm{NaCl}, 5.6 \mathrm{mM} \mathrm{KCl}$, $3.6 \mathrm{mM} \mathrm{NaHCO}, 2.3 \mathrm{mM} \mathrm{CaCl} 2,4.4 \mathrm{mM}$ D-glucose, 5 mM HEPES, pH 7.4) containing either $100 \mu \mathrm{M}$ ARG or combinations of $100 \mu \mathrm{M}$ ARG with or without $30 \mu \mathrm{M}$ L-NAME, $20 \mu \mathrm{M}$ CMP-C, or $30 \mu \mathrm{M}$ CDB for $2 \mathrm{~h}$. Continuous effect was assessed by incubating cultured cells with $100 \mu \mathrm{M}$ ARG (and/or other agents) in daily refreshed medium consecutively for 7 days, after which cells are washed twice with $1 \mathrm{X}$ phosphate buffered saline (PBS), and challenged with Locke's buffer containing similar treatment conditions, for $2 \mathrm{hr}$.

After incubation, cells are then detached from the 6-well plates using trypsin-EDTA, centrifuged at $2000 \times \mathrm{g}$ for $30 \mathrm{sec}$ at $4^{\circ} \mathrm{C}$, and washed twice using $1 \mathrm{X}$ PBS. Cell lysis is carried out at $2-8^{\circ} \mathrm{C}$, centrifuged at $13,000 \times$ g for 5 $\min$ at $4^{\circ} \mathrm{C}$, and the resultant supernatant was used to test eNOS expression, to monitor cellular eNOS, AMPK and GLUT1 expression, besides $\mathrm{NO}_{2}^{-} / \mathrm{NO}_{3}^{-}$, and glucose accumulation according to instructions provided by the respective manufacturer and correction for protein content [27] is applied.

\section{Superoxide $\left(\mathrm{O}_{2}^{--}\right)$measurement using EPR Spectroscopy}

In spin trapping measurements of oxygen radical (viz $\mathrm{O}_{2}^{--}$) generation were performed on $5 \times 10^{6}$ cells $/ \mathrm{mL}$ in PBS with DMPO at a final concentration of $50 \mathrm{mM}$. The DMPO ( $>97 \%$ pure) was purchased from Aldrich and further purified by double distillation. EPR spectra were recorded in a quartz flat cell at room temperature with a Bruker ER 300 spectrometer operating at X-band with a $100-\mathrm{kHz}$ modulation frequency and a TM 110 cavity, as described [28]. The microwave frequency and magnetic field were precisely measured using an EIP 575 frequency counter and Bruker ER 035 NMR gauss meter. Quantitation of the free radical signals was performed by comparing the double integral of the observed signal with that of a known concentration of the 2,2,6,6,tetramethyl-1-piperidinyloxy free radical in aqueous solution as previously described [28].

\section{Peroxy $\left(\mathrm{ONOO}^{-}\right)$measurement}

Aminophenyl fluorescein (APF) developed by Tetsuo Nagano et. al., [29] and commercially made available by Cell Technology (Mountain View, CA), was used to determine $\mathrm{ONOO}^{-}$in whole cells; as it has little reactivity towards other hydroxyl reactive oxygen species such as: hypochlorite ( $\left.{ }^{-} \mathrm{OCl}\right)$, singlet oxygen (021), $\mathrm{O}_{2}{ }^{-}$, hydrogen peroxide $\left(\mathrm{H}_{2} \mathrm{O}_{2}\right)$, $\mathrm{NO}$, and alkyl peroxide $\left(\mathrm{RO}_{2}^{*}\right)$. Cells, during the final $15 \mathrm{~min}$ of their treatment period are exposed to a final individual concentrations of $5 \mu \mathrm{M}$ APF, incubated in dark at $25^{\circ} \mathrm{C}$, washed twice with $1 \mathrm{X}$ PBS, followed by flow-cytometer measurement, with excitation and emission wavelengths of 488 and $515 \mathrm{~nm}$ respectively. The dye concentrations of $5 \mu \mathrm{M}$ for APF are carefully selected after experimental optimization that avoided cell death. This methodology was found to be at least 1 fold more sensitive than traditional chemiluminescence measurement of $\mathrm{ONOO}^{-}$. This method was also effective in measuring $\mathrm{ONOO}^{-}$in whole viable cellular treatments under physiological conditions.

\section{AMPK activity}

After treatment, cells were immediately washed with $2 \mathrm{ml}$ of ice-cold 1X PBS buffer and scraped with a rubber spatula in lysis buffer $(20 \mathrm{mM}$ Tris, $\mathrm{pH} 7.5,150 \mathrm{mM}$ $\mathrm{NaCl}, 1 \mathrm{mM}$ EDTA, $1 \mathrm{mM}$ EGTA, 1\% Triton X-100, $2.5 \mathrm{mM}$ sodium pyrophosphate, $1 \mathrm{mM}$ ß-glycerophosphate, $1 \mathrm{mM} \mathrm{Na} \mathrm{VO}_{4}, 1 \mu \mathrm{g} / \mathrm{ml}$ leupeptin, $1 \mathrm{mM}$ phenylmethylsulfonyl fluoride). The cell lysates were then sonicated twice for $10 \mathrm{~s}$ and then centrifuged at 14,000 $\times \mathrm{g}$ for $20 \mathrm{~min}$ at $4^{\circ} \mathrm{C}$. The pellets were discarded and supernatants were assayed for protein concentration (Lowry, 1951 \#302). Duplicate tubes from each sample were prepared and were mixed with $500 \mu \mathrm{l}$ of IP buffer (lysis buffer plus $1 \mathrm{M} \mathrm{NaCl}$ and $1 \mathrm{mM}$ dithiothreitol). AMPK was then immunoprecipitated by adding $10 \mu \mathrm{g}$ of polyclonal antibody against AMPK (Cell Signaling) and $25 \mu \mathrm{l}$ of protein A-G agarose (Santa Cruz Biotechnology) and incubated at $4^{\circ} \mathrm{C}$. After centrifugation $(14,000 \times \mathrm{g}, 1 \mathrm{~min})$, the beads were washed with IP buffer and then twice with 10X reaction buffer (400 mM HEPES, pH 7.4, $800 \mathrm{mM}$ $\mathrm{NaCl}, 50 \mathrm{mM} \mathrm{MgCl} 2,1 \mathrm{mM}$ dithiothreitol). The AMPK activity was assayed by adding $50 \mu \mathrm{l}$ of reaction mixtures, consisting of $5 \mu \mathrm{l}$ of reaction buffer, $10 \mu \mathrm{l}$ of SAMS peptide $(1 \mathrm{mg} / \mathrm{ml}), 10 \mu \mathrm{l}$ of ATP working stock consisting of $0.1 \mu \mathrm{l}$ of $100 \mathrm{mM}$ ATP, $1 \mu \mathrm{l}$ of $\left[{ }^{32} \mathrm{P}\right]$ ATP, and $8.9 \mu \mathrm{l}$ of $\mathrm{H}_{2} 0,25 \mu \mathrm{l} \mathrm{H}_{2}$, or $25 \mu \mathrm{l}$ of $400 \mu \mathrm{M}$ AMP and incubated at $37^{\circ} \mathrm{C}$ for $10 \mathrm{~min}$. The beads were quickly pelleted and $25 \mu \mathrm{l}$ of supernatant was spotted onto P81 Whatman paper. The filter papers were then washed 4-5 times with $1 \%$ phosphoric acid. After the final wash, the filters were quickly dried and counted in a scintillation counter. The difference between the presence and absence of $\left[{ }^{32} \mathrm{P}\right] \mathrm{AMP}$ is calculated as the AMPK activity. 


\section{LC-MS assay}

Concentration of ${ }^{13} \mathrm{C}_{6}$-glucose in cells and medium were determined by LC-MS/MS assay previously described [30]. Briefly, aliquot of $20 \mu \mathrm{L}$ (of the cellular lysate sample or the medium) was mixed with internal standards (20 $\mu \mathrm{L}$ of $1 \mu \mathrm{M},{ }^{13} \mathrm{C}_{6}$-ARG, $20 \mu \mathrm{L}$ of $1 \mu \mathrm{M} \mathrm{D} \mathrm{D}_{4}$-CIT and $20 \mu \mathrm{l}$ of $250 \mathrm{nM} \mathrm{D}_{7} \mathrm{ADMA}$ ) and protein was removed by adding of $120 \mu \mathrm{L}$ of acetonitrile containing $0.5 \%$ acetic acid and $0.025 \%$ trifluoroacetic acid. After centrifugation at $10,000 \times \mathrm{g}$ for $20 \mathrm{~min}$, the supernatant was collected for analysis.

\section{Statistical analysis}

Data are presented as mean \pm standard deviation after analyzing 6 independently generated samples for each treatment condition $(n=6)$, unless otherwise stated. Statistical comparisons among groups were performed using one-way analysis of variance (ANOVA), followed by Fisher's and Tukey's post-hoc test procedure (Minitab 16.0). Statistical significance was concluded when $\mathrm{p}<0.05$.

\section{Results \\ Effect of cellular regulation on eNOS function and oxidative stress}

HUVEC exposed to $100 \mu \mathrm{M}$ ARG for a short-term or acute period of $2 \mathrm{~h}$ showed significant increase in total nitrite/nitrate $\left(\mathrm{NO}_{2}^{-} / \mathrm{NO}_{3}^{-}\right)$levels from $1.7 \pm 0.2$ to $4.3 \pm$ 0.3 , which were measured as stable end derivative of $\mathrm{NO}$ in cells, to determine eNOS activity. The increase in cellular $\mathrm{NO}_{2}^{-} / \mathrm{NO}_{3}^{-}$reduced significantly to levels below control conditions in cells chronically or continuously exposed to $100 \mu \mathrm{M}$ ARG for 7 days and during ARG co-incubation with $30 \mu \mathrm{M}$ CMP-C, that inhibits AMPK activity (Figure 1A). Short-term or continuous ARG coincubation of cells with $30 \mu \mathrm{M}$ L-NAME resulted in reduction in $\mathrm{NO}_{2}^{-} / \mathrm{NO}_{3}^{-}$to below detection limit, thus indicating complete inhibition in cellular eNOS activity. Cells treated with ARG in combination with $30 \mu \mathrm{M}$ CDB showed significant progressive improvement in eNOS function, with increase in $\mathrm{NO}_{2}^{-} / \mathrm{NO}_{3}^{-}$that was seen during short-term $(4.4 \pm 0.4)$ and continuous $(5.7 \pm 0.4)$ treatments.

The increase in $\mathrm{NO}_{2}^{-} / \mathrm{NO}_{3}^{-}$after short-term $100 \mu \mathrm{M}$ ARG exposure was accompanied with at least one-fold increase in both cellular $\mathrm{O}_{2}^{--}$and $\mathrm{ONOO}^{-}$, which remained elevated during continuous ARG exposure (Figure 1B and $\mathrm{C}$ ). Loss in AMPK activity that was observed in cells treated with $100 \mu \mathrm{M}$ ARG in the presence of $30 \mu \mathrm{M}$ CMP-C mimicked the elevated $\mathrm{O}_{2}^{*-}$ and $\mathrm{ONOO}^{-}$levels that were seen during ARG exposure, while cellular coexposure to either $30 \mu \mathrm{M}$ L-NAME or CDB during short-term or continuous co-treatment with $100 \mu \mathrm{M}$ ARG retained the level of $\mathrm{O}_{2}^{--}$and $\mathrm{ONOO}^{-}$to those observed during control conditions.
Effect of cellular regulation on ${ }^{13} \mathrm{C}_{6}$ glucose transport

Short-term exposure in cells with $100 \mu \mathrm{M}$ ARG increased cellular ${ }^{13} \mathrm{C}_{6}$ glucose uptake by one-fold, to $49 \pm$ $3.2 \mu \mathrm{M}$, which were maintained at levels similar to control conditions $(29 \pm 1.8)$ in cells treated for $2 \mathrm{~h}$ with $100 \mu \mathrm{M}$ ARG in the presence of either $30 \mu \mathrm{M}$ L-NAME or $30 \mu \mathrm{M}$ CMP-C (Figure 2A). Continuous exposure of cells with ARG alone or in combination with either L-NAME or CMP-C significantly reduced ${ }^{13} \mathrm{C}_{6}$ glucose uptake to levels that were at least one-fold below control conditions. Those cells co-incubated with $100 \mu \mathrm{M}$ ARG and $30 \mu \mathrm{M}$ CDB maintained the one-fold shortterm increase in ${ }^{13} \mathrm{C}_{6}$ glucose uptake to $53 \pm 4.1 \mu \mathrm{M}$ during continuous exposure.

The expression level of GLUT-1 protein in HUVEC remained unchanged from control during short-term $2 \mathrm{~h}$ treatment of cells with ARG, in the presence or absence of the inhibitory agents for eNOS, AMPK activity or cellular glucose production (Figure 2B). However, at least one-third fold decrease in GLUT-1 protein expression was seen in those cells exposed continuously for 7 days in medium containing $100 \mu \mathrm{M}$ ARG or when combined with $30 \mu \mathrm{M}$ of either L-NAME or CMP-C. Continuous exposure of cells with $100 \mu \mathrm{M}$ ARG in combination with $30 \mu \mathrm{M}$ CDB for 7 days resulted in one-third fold higher GLUT-1 expression than control.

\section{Effect of cellular regulation on overall glucose accumulation} Cells exposed to $100 \mu \mathrm{M}$ ARG or when co-treated with either $30 \mu \mathrm{M}$ of either L-NAME or CMP showed at least half-fold increase in overall cellular glucose levels during short-term exposure, that resulted in at least one-fold increase in overall cellular glucose after continuous treatment (Figure 3A). A progressive increase in glucose accumulation in extracellular medium was also observed during continuous exposure to ARG in the presence or absence of L-NAME or CMP-C co-treatment (Figure 3B). Cells incubated with ARG in the presence of $30 \mu \mathrm{M} C D B$, maintained cellular and medium glucose levels that resembled control conditions even after continuous exposure.

\section{AMPK expression and activity during cellular exposure conditions}

Short-term exposure of cells to either $100 \mu \mathrm{M}$ ARG alone or in combination with $30 \mu \mathrm{M}$ concentration of L-NAME, CDB or CMP-C, showed no significant variation in AMPK expression levels (Figure 4A). While continuous exposure of cells with $100 \mu \mathrm{M}$ ARG or in combination with $30 \mu \mathrm{M}$ L-NAME or CMP-C caused reduction in AMPK expression levels to be at least one-third fold below control, continuous co-incubation of those cells with $100 \mu \mathrm{M}$ ARG and $30 \mu \mathrm{M}$ CDB saw at least one-forth fold increase in their overall AMPK expression. 

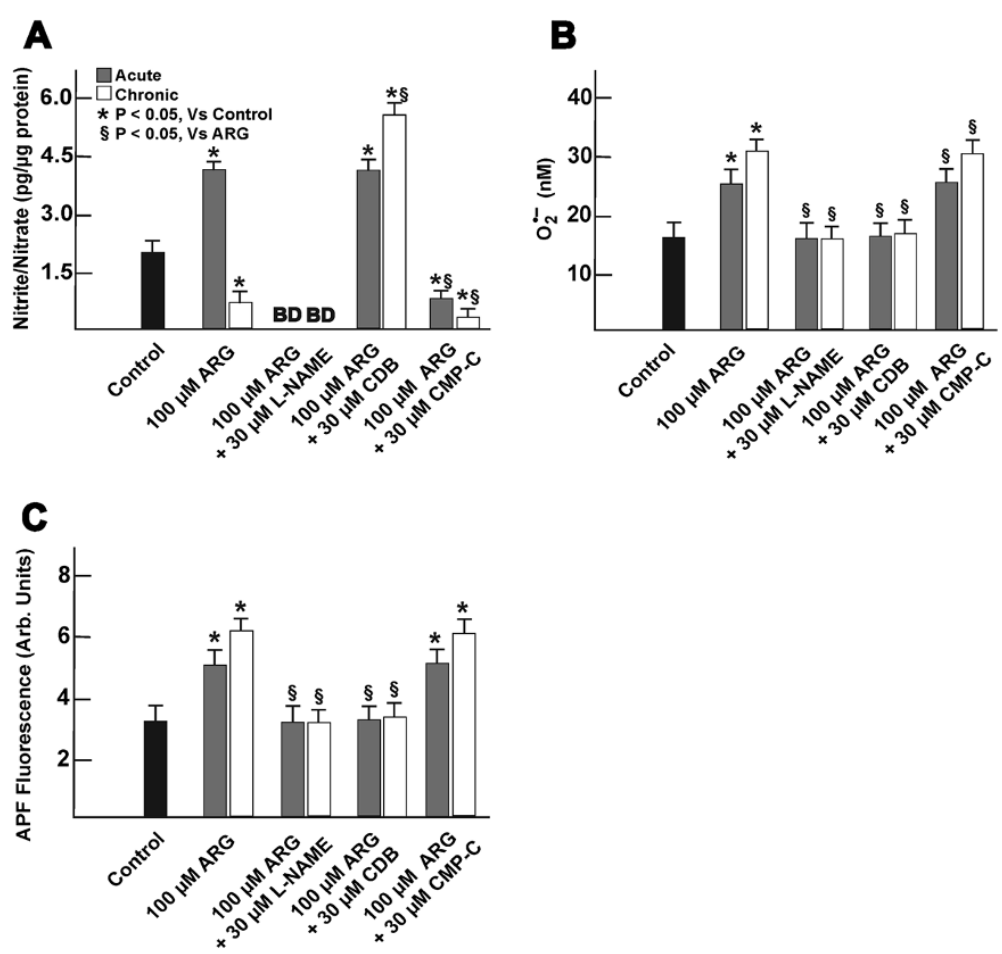

Figure 1 Comparing the effects of ARG co-incubation with various agents on eNOS function and oxidative stress. HUVEC were incubated with either $100 \mu \mathrm{M}$ ARG for $2 \mathrm{~h}$ in buffer (short-term or acute exposure), or for 7 days in culture medium and challenged for $2 \mathrm{~h}$ in buffer (continuous or chronic exposure), in the presence or absence of other agents. Total $\mathrm{NO}_{2}^{-} / \mathrm{NO}_{3}^{-}$assay measurement (A) shows the importance in maintaining eNOS and AMPK activity with cellular NO production. The inhibition of AMPK or eNOS function, increased cellular $\mathrm{O}_{2}^{-}$ (B) and $\mathrm{ONOO}^{-}$(C), that were maintained close to control conditions when cellular glucose synthesizing pathway was disrupted. $n=6$. * represents significant variation between control and treatment groups at $p<0.05$. $\S$, represents variation in treatment groups from cells treated with $100 \mu \mathrm{M}$ ARG, at $p<0.05$.

Short-term cellular exposure to $100 \mu \mathrm{M}$ ARG improved cellular AMPK activity, but experienced at least 1.5 fold reduction in AMPK activity from control during continuous exposure (Figure 4B). Co-incubation of cells with $100 \mu \mathrm{M}$ ARG and $30 \mu \mathrm{M}$ L-NAME progressively decreased AMPK activity below control during acute and continuous treatments, and was totally abolished in cells co-treated with $100 \mu \mathrm{M}$ ARG and $30 \mu \mathrm{M}$ CMP-C. Short-term and continuous cellular co-exposure to $100 \mu \mathrm{M}$ ARG and $30 \mu \mathrm{M}$ CDB saw progressive increase in AMPK activity.

\section{Discussion}

Our study provides the primary evidence to suggest AMPK regulation as the fundamental contributor in modulating ARG response during short-term and continuous supplementation. The therapeutic effect of ARG is based on its ability to act as the endogenous substrate for eNOS in producing NO [31]. Since, endogenous AMPK activation in cells is considered to be vital for eNOS activation via phosphorylation [32], the AMPK-eNOS-NO pathway seems to play an essential role in maintaining vascular function and homeostasis.
The NO generated by eNOS via ARG utilization, is known to be required for the initial activation of AMPK [32], possibly via calmodulin dependent protein kinase kinase (CaMKK) $[33,34]$ or other mechanistic pathways $[35,36]$. While NO controls AMPK function through activation of guanylyl cyclase, $\mathrm{ONOO}^{-}$that is formed by the reaction between $\mathrm{NO}$ and $\mathrm{O}_{2}^{*-}$, can also impose its regulation on AMPK activation by impairing guanylyl cyclase [37-39]. Thus it can be predicted that the NOCaMKK-AMPK axis to be predominant in displaying the ARG beneficial effect during short-term exposure, whereas the $\mathrm{ONOO}^{-}$-AMPK axis is likely to operate the deleterious effects of continuous ARG exposure. The potential ability for AMPK to act as the fundamental modulator of ARG cellular response during shortterm and continuous ARG supplementation is validated in our studies using various inhibitors, whose dosage levels were determined after a dose-response study that showed minimal cell death.

HUVEC exposure for a short period of $2 \mathrm{~h}$ to $100 \mu \mathrm{M}$ ARG, caused a substantial 1.5-fold increase in $\mathrm{NO}_{2}^{-} / \mathrm{NO}_{3}^{-}$ level that got significantly reduced from control conditions of $1.7 \pm 0.2$ to $0.5 \pm 0.1 \mathrm{pg} / \mu \mathrm{g}$ protein, when cellular 


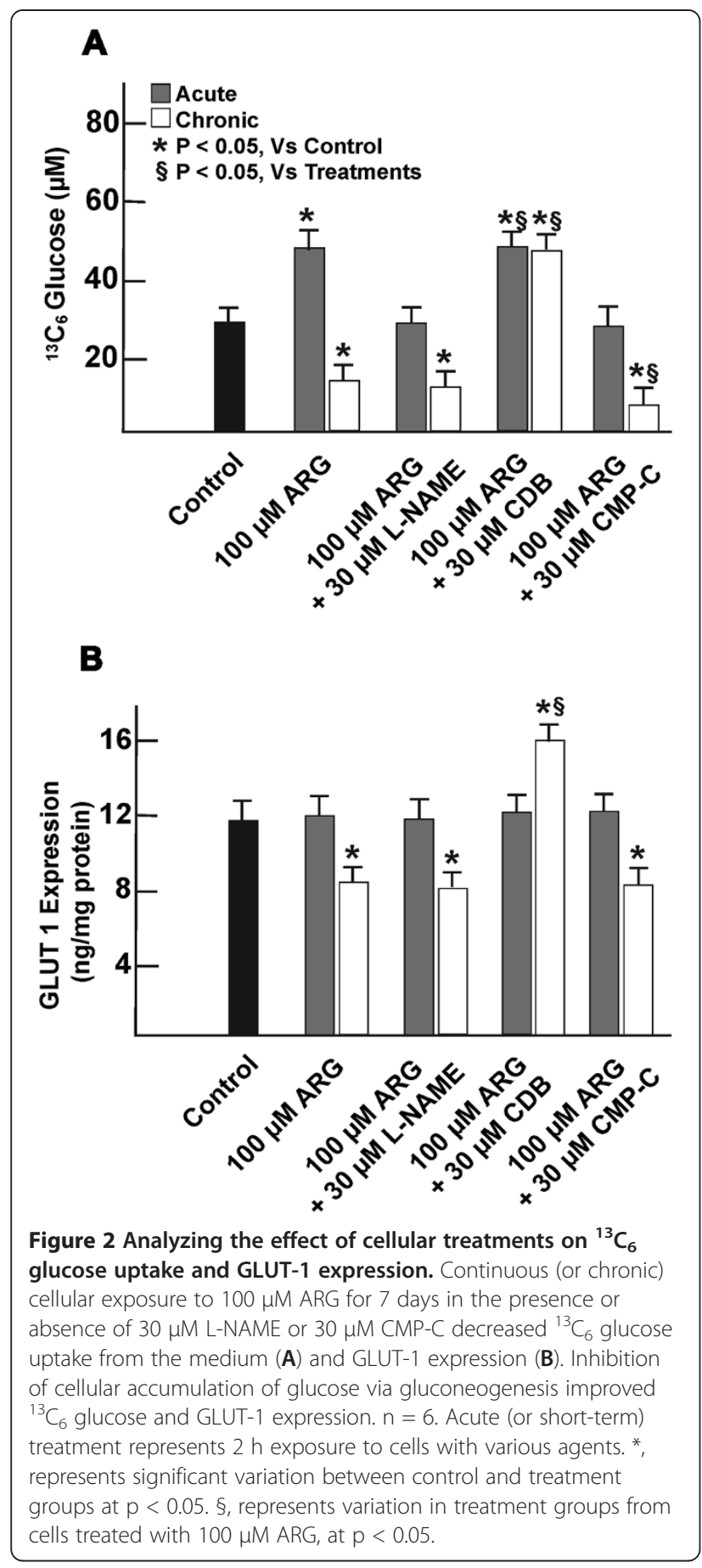

AMPK activity was inhibited with $30 \mu \mathrm{M}$ CMP-C during $100 \mu \mathrm{M}$ ARG co-treatment. The $\mathrm{NO}_{2}^{-} / \mathrm{NO}_{3}^{-}$level were measured in our study (as a stable end-derivatives of NO) instead of cellular NO for determining eNOS activity, due to the short-half life of $\mathrm{NO}$, in the range of few seconds. The decrease in $\mathrm{NO}_{2}^{-} / \mathrm{NO}_{3}^{-}$seen during short-term cellular co-incubation for $2 \mathrm{~h}$ with $100 \mu \mathrm{M}$ ARG and $30 \mu \mathrm{M}$

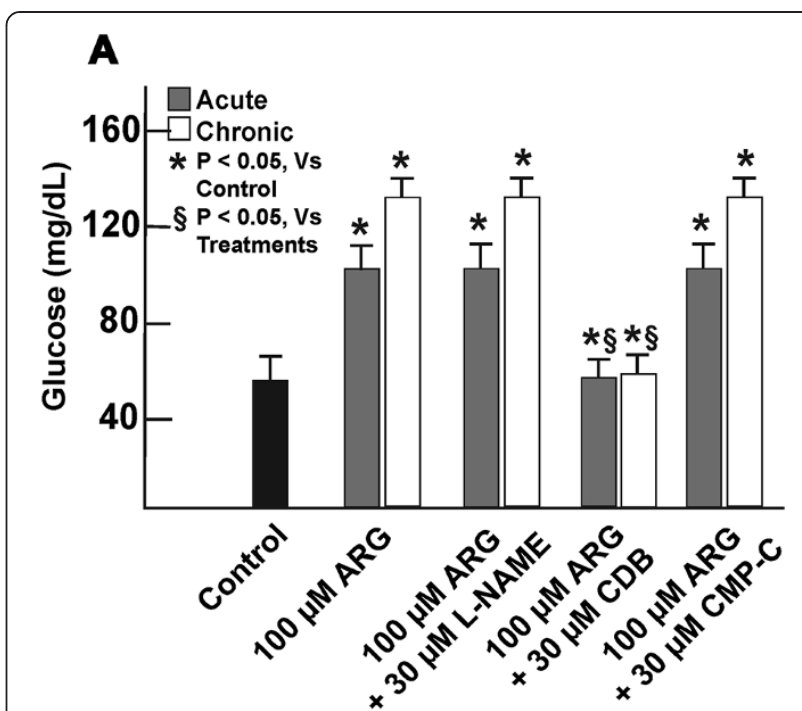

B 0 Control

- $100 \mu$ M ARG

$0100 \mu \mathrm{M}$ ARG+ $30 \mu \mathrm{M}$ CDB

- $100 \mu \mathrm{M}$ ARG+ $30 \mu \mathrm{M}$ L-NAME

$\triangle 100 \mu \mathrm{M} A R G+30 \mu \mathrm{M}$ CMP-C

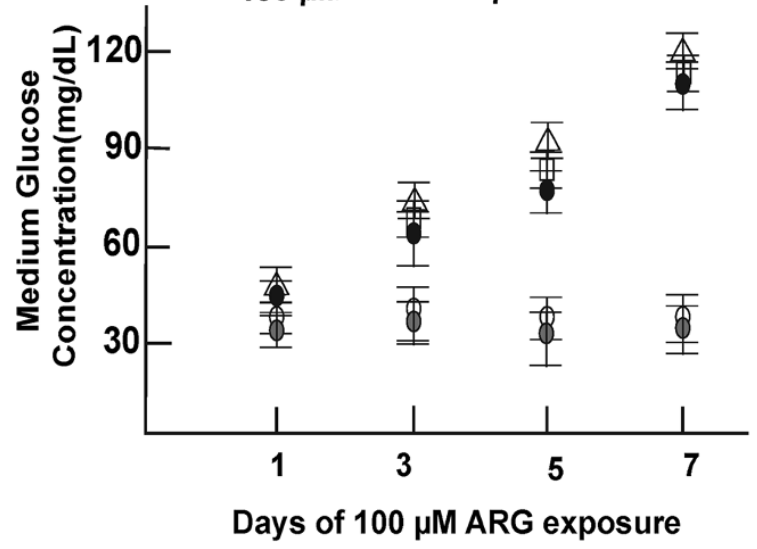

Figure 3 Measurement of total glucose in cells and medium. Short-term (acute) or continuous (chronic) cellular exposure to $100 \mu \mathrm{M}$ ARG in the presence or absence of $30 \mu \mathrm{M}$ L-NAME or CMP-C resulted in increase in cellular glucose (A). A progressive increase of glucose in the cell medium was also observed during ARG continuous treatment of cells for 7 days or when co-incubated with $30 \mu \mathrm{M}$ L-NAME or CMP-C (B). Cells co-incubated with $100 \mu \mathrm{M}$ ARG and $30 \mu \mathrm{M}$ CDB, had glucose levels in cells and in the medium at levels similar to control conditions. $n=6 .{ }^{*}$, represents significant variation between control and treatment groups at $p<0.05$. , represents variation in treatment groups from cells treated with $100 \mu \mathrm{M}$ ARG, at $p<0.05$.

CMP-C was comparable to those cells continuously exposed to $100 \mu \mathrm{M}$ ARG alone; and also resulted in concomitant one-fold increase in $\mathrm{O}_{2}^{--}$and $\mathrm{ONOO}^{-}$, thereby suggesting the development of oxidative stress under these tested conditions. While the mechanism involved in how AMPK activation is lost during continuous ARG exposure is still under investigation in our lab, the present study 


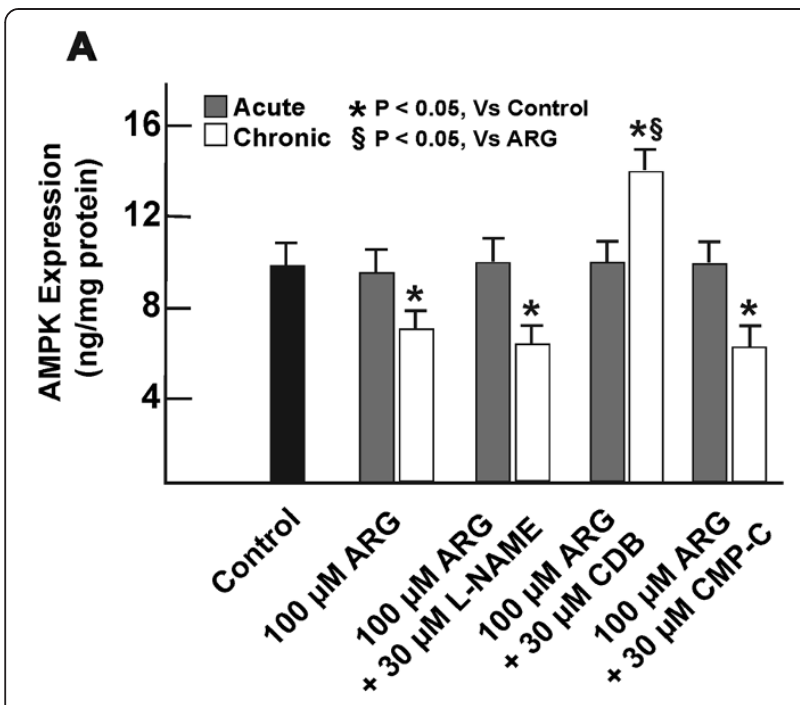

B

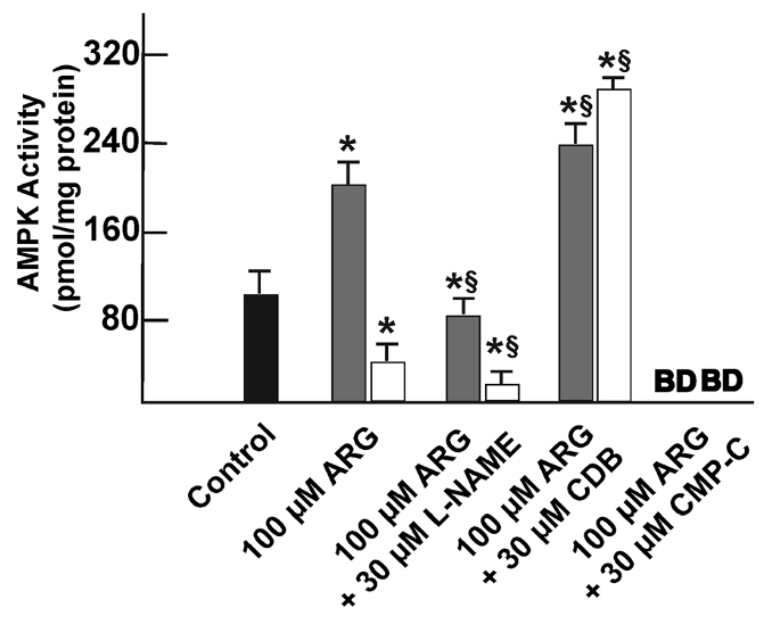

Figure 4 Measurement of cellular AMPK activity and expression. AMPK expression decreased only during continuous (or chronic) exposure to $100 \mu \mathrm{M}$ ARG in the presence or absence of $30 \mu \mathrm{M}$ CMP-C or L-NAME for 7 days $(\mathbf{A})$. Continuous co-incubation of cells with $100 \mu \mathrm{M}$ ARG and $30 \mu \mathrm{M}$ CDB for 7 days increased AMPK expression. Cells incubated short-term (or acutely) with $100 \mu \mathrm{M}$ ARG for $2 \mathrm{~h}$ or when continuous co-treated with $100 \mu \mathrm{M}$ ARG and $30 \mu \mathrm{M}$ CDB showed increase in their AMPK activity (B). Co-incubation of cells with $100 \mu \mathrm{M}$ ARG and either $30 \mu \mathrm{M}$ CMP-C or L-NAME suppressed AMPK activity under all treatment conditions. $n=6 .{ }^{*}$, represents significant variation between control and treatment groups at $p<0.05$. $\S$, represents variation in treatment groups from cells treated with $100 \mu \mathrm{M}$ ARG, at $\mathrm{p}<0.05$.

provides fundamental evidence suggesting AMPK modulatory to affect eNOS function and cellular oxidative stress during ARG supplementation.

Inhibition of eNOS activity with $30 \mu \mathrm{M}$ L-NAME during cellular co-incubation with $\mathrm{ARG}$, reduced $\mathrm{NO}_{2}^{-} / \mathrm{NO}_{3}^{-}$ to below detection limit. The reduction in $\mathrm{NO}_{2}^{-} / \mathrm{NO}_{3}^{-}$was also accompanied by decreases seen in AMPK activity level during short-term and continuous exposure, thus suggesting the importance of maintaining eNOS activity, for subsequent activation of AMPK in cells. Although co-incubation of cells with ARG and L-NAME completely blocked eNOS activity and avoided NO generation, an increase in cellular $\mathrm{O}_{2}^{--}$and $\mathrm{ONOO}^{-}$level was not observed, as L-NAME exposure in cells is known to have the ability in controlling both $\mathrm{NO}$ and $\mathrm{O}_{2}^{--}$production [40-42]. Thus the use of L-NAME undermines the understanding of ARG response towards cellular oxidative stress under these tested conditions. The use of $30 \mu \mathrm{M} \mathrm{N}{ }^{\mathrm{G}}$-monomethyl-L-arginine (L-NMMA) in place of L-NAME abolished eNOS activity in cells when coincubated with $100 \mu \mathrm{M}$ ARG, with at least an one-fold increase in $\mathrm{O}_{2}^{--}$and $\mathrm{ONOO}^{-}$to $32 \pm 3.4 \mathrm{nM}$ and $5.9 \pm$ 0.1 Arb Units, that was observed from control conditions of $14.8 \pm 2.1 \mathrm{nM}$ and $3.1 \pm 0.1$ Arb Units, respectively. A concomitant decrease in AMPK activity was also observed during $100 \mu \mathrm{M}$ ARG and $30 \mu \mathrm{M}$ L-NMMA co-incubation, that were identical to cellular co-treatments with $100 \mu \mathrm{M}$ ARG and $30 \mu \mathrm{M}$ L-NAME. These results suggest eNOS function and AMPK activity to be interrelated, but require further evaluation to better delineate their relationship. The use of $30 \mu \mathrm{M}$ L-NAME or L-NMMA as eNOS inhibitor showed no reduction in eNOS gene expression, when analysed by qPCR (data not shown). Our earlier studies have shown at least a $30 \%$ decrease in eNOS protein expression from control in cells continuously exposed with either $100 \mu \mathrm{M}$ ARG alone or in combination with $30 \mu \mathrm{M}$ L-NAME or L-NMMA [20], suggesting post-translational modification in these cells.

The use of $30 \mu \mathrm{M} \mathrm{CDB}$, as inhibitor for gluconeogenesis pathway in combination with ARG showed significant increase in $\mathrm{NO}_{2}^{-} / \mathrm{NO}_{3}^{-}$, with $\mathrm{O}_{2}^{--}$and $\mathrm{ONOO}^{-}$levels same as control. The $30 \mu \mathrm{M} \mathrm{CDB}$ used in the study did not exhibit any anti-oxidant properties, thereby avoiding the possibility of any artifact in our results. We selected the Fructose-bis-phosphatase (FBPase) inhibitor, CDB, as a probe to modify cellular glucose metabolism, not only because FBPase is a rate-controlling enzyme within the gluconeogenesis pathway, but also because it functions only within the gluconeogenesis pathway, unlike the other two rate limiting enzymes, phosphoenolpyruvate carboxykinase and glucose 6-phosphatase [43,44]. Moreover, adults who are genetically deficient in FBPase activity exhibit relatively normal clinical profiles provided they control their diet and avoid prolonged fasting $[45,46]$.

Primary cell culture studies of various types $[47,48]$, such as the one presented in our study have demonstrate that $\mathrm{NO}$ or the intermediates derived from the $\mathrm{NO} / \mathrm{O}_{2}^{--}$ reaction are not appreciably cytotoxic under the conditions employed $[20,21,49]$. Under biological conditions where NO has been speculated to be a toxic substance (i.e., cytolytic action of the immune system and ischemia 
reperfusion), other potent toxic agents such as hydrogen peroxide and superoxide also are present $[47,48]$. This underscores the importance of investigating the interplay between $\mathrm{NO}$ and reactive oxygen species in the mediation of cytotoxicity. Further, the dosage level of the inhibitors used in the present study were implemented after initial dose-response study that avoided cell death as well as anti-oxidant properties, hence eliminating falsepositive artifacts in the presented results.

This allowed us to consider the possible relationship between AMPK cellular regulations on glucose uptake from the medium versus endogenous glucose synthesis. To better understand whether AMPK activation is crucial in regulating the mode of cellular glucose accumulation (viz., glucose uptake versus cellular synthesis,) we allowed the cells to be grown in medium containing $0.1 \mathrm{mM}^{13} \mathrm{C}_{6}$ glucose, in addition to $4.3 \mathrm{mM}$ D-glucose, resulting in a final glucose concentration of $4.4 \mathrm{mM}$ that is equivalent to physiological conditions. The use of physiological medium condition in our present study helped us in better illustrating the cellular responses to various ARG challenges that were otherwise difficult to measure.

The amount of total glucose accumulation (endogenous glucose $+{ }^{13} \mathrm{C}_{6}$ glucose) in cells was analyzed after exposure to $100 \mu \mathrm{M}$ ARG in the presence or absence of the inhibiting agents for eNOS function, AMPK activity or gluconeogenesis. Those cells subjected to AMPK and eNOS activity inhibition during ARG co-exposure (during short-term and continuous treatment conditions) showed significant increase in overall glucose accumulation with decrease in glucose uptake levels from control. Cellular inhibition of gluconeogenesis pathway with $\mathrm{CDB}$ in the presence of ARG increased ${ }^{13} \mathrm{C}_{6}$-glucose level similar to those observed during short-term exposure of cells to $100 \mu \mathrm{M}$ ARG. These short-term increase in ${ }^{13} \mathrm{C}_{6}$ glucose uptake level was successfully retained during continuous CDB and ARG co-exposures. The inhibition of gluconeogenesis pathway, also demonstrated a concomitant increase in the expression of cellular GLUT-1. The AMPK expression and activity were also positively improved under these conditions.

These results from this study suggest that ARG mediated short-term therapeutic benefits to be initiated via the activation of AMPK, which stimulates downstream NO release by maintaining eNOS activity and allowing glucose to accumulate only via cellular transport. The dysfunction in AMPK enzyme activity affected eNOS function, decreased glucose uptake from medium, increased cellular glucose synthesis and oxidative stress. All of these events seen during AMPK dysfunction are concomitant with those reported to occur during continuous ARG supplementation [50]. Thus the present study provides the primary evidence of AMPK regulation as the primary modulator for ARG cellular response, based on two time points; $2 \mathrm{~h}$ (short-term or acute exposure) and 7 days (continuous or chronic exposure). Multiple time points of 1,3 , and 5 days, need to be evaluated in the future to better resolve the role of AMPK. Further validation is also presently underway to discuss the role of calcium flux and other processes that are involved to better explain the cascade of pharmacological events that regulates AMPK function during ARG supplementation. Better understanding of these pharmacological events will help to inform the design and evaluation of future clinical trials involving ARG.

\section{Competing interests}

The authors declare that they have no competing interests.

\section{Authors' contribution}

SM performed the $\mathrm{O}_{2}^{--}$measurement by EPR-Spin trap, ONOO- and LC-MS assays. HP, JB, and NS helped in cell treatment, and sample collection. They performed analysis of cellular glucose level, and evaluated the expression levels of eNOS, GLUT-1 and AMPK. They also determined eNOS and AMPK activity and protein content in cell treatments. All authors read and approved the final manuscript.

\section{Acknowledgements}

This work is supported in part by UNE mini-grant and Emily Jane Etherton Charitable Lead Trust.

Received: 11 February 2013 Accepted: 25 May 2013

Published: 29 May 2013

\section{References}

1. L-Arginine Medlineplus supplements. Medlineplus 2011. http://www.nlm. nih.gov/medlineplus/druginfo/natural/875.html.

2. Ceremuzynski L, Chamiec T, Herbaczynska-Cedro K: Effect of supplemental oral L-arginine on exercise capacity in patients with stable angina pectoris. Am J Cardiol 1997, 80:331-333.

3. Maxwell AJ, Anderson BE, Cooke JP: Nutritional therapy for peripheral arterial disease: a double-blind, placebo-controlled, randomized trial of HeartBar. Vasc Med 2000, 5:11-19.

4. Bednarz K: Am Ende der Welt: eine Reise durch Feuerland und Patagonien. 1. Aufl. edn. Berlin: Rowohlt; 2004.

5. Hambrecht R, Hilbrich L, Erbs S, Gielen S, Fiehn E, Schoene N, Schuler G: Correction of endothelial dysfunction in chronic heart failure: additional effects of exercise training and oral L-arginine supplementation. J Am Coll Cardiol 2000, 35:706-713.

6. Rodriguez PC, Quiceno DG, Ochoa AC: L-arginine availability regulates T-lymphocyte cell-cycle progression. Blood 2007, 109:1568-1573.

7. Shang HF, Wang YY, Lai YN, Chiu WC, Yeh SL: Effects of arginine supplementation on mucosal immunity in rats with septic peritonitis. Clin Nutr 2004, 23:561-569.

8. Zhu H, Liu Y, Xie X, Huang J, Hou Y: Effect of L-arginine on intestinal mucosal immune barrier function in weaned pigs after Escherichia coli LPS challenge. Innate Immun 2013, 19:242-52.

9. Baydoun AR, Emery PW, Pearson JD, Mann GE: Substrate-dependent regulation of intracellular amino acid concentrations in cultured bovine aortic endothelial cells. Biochem Biophys Res Commun 1990, 173:940-948.

10. Zhou M, Martindale RG: Arginine in the critical care setting. J Nutr 2007, 137:1687S-1692S.

11. Raghupathy $\mathrm{R}$, Billett $\mathrm{HH}$ : Promising therapies in sickle cell disease. Cardiovasc Hematol Disord Drug Targets 2009, 9:1-8.

12. Tangphao O, Grossmann M, Chalon S, Hoffman BB, Blaschke TF: Pharmacokinetics of intravenous and oral L-arginine in normal volunteers. Br J Clin Pharmacol 1999, 47:261-266.

13. Bednarz B, Jaxa-Chamiec T, Maciejewski P, Szpajer M, Janik K, Gniot J, Kawka-Urbanek T, Drozdowska D, Gessek J, Laskowski H: Efficacy and safety of oral l-arginine in acute myocardial infarction. Results of the 
multicenter, randomized, double-blind, placebo-controlled ARAMI pilot trial. Kardiol Pol 2005, 62:421-427.

14. Kakoki M, Kim HS, Edgell CJ, Maeda N, Smithies O, Mattson DL: Amino acids as modulators of endothelium-derived nitric oxide. Am J Physiol Renal Physiol 2006, 291:F297-304

15. Oka RK, Szuba A, Giacomini JC, Cooke JP: A pilot study of L-arginine supplementation on functional capacity in peripheral arterial disease. Vasc Med 2005, 10:265-274.

16. Pollock JS, Forstermann U, Mitchell JA, Warner TD, Schmidt HH, Nakane M, Murad F: Purification and characterization of particulate endotheliumderived relaxing factor synthase from cultured and native bovine aortic endothelial cells. Proc Natl Acad Sci U S A 1991, 88:10480-10484.

17. Wilson AM, Harada R, Nair N, Balasubramanian N, Cooke JP: L-arginine supplementation in peripheral arterial disease: no benefit and possible harm. Circulation 2007, 116:188-195.

18. Schulman SP, Becker LC, Kass DA, Champion HC, Terrin ML, Forman S, Ernst KV, Kelemen MD, Townsend SN, Capriotti A, et al: L-arginine therapy in acute myocardial infarction: the Vascular Interaction With Age in Myocardial Infarction (VINTAGE MI) randomized clinical trial. JAMA 2006, 295:58-64.

19. Chen J, Kuhlencordt P, Urano F, Ichinose H, Astern J, Huang PL: Effects of chronic treatment with L-arginine on atherosclerosis in apoE knockout and apoE/inducible NO synthase double-knockout mice. Arterioscler Thromb Vasc Biol 2003, 23:97-103.

20. Mohan S, Wu CC, Shin S, Fung HL: Continuous exposure to L: -arginine induces oxidative stress and physiological tolerance in cultured human endothelial cells. Amino Acids 2011, 2011:2011.

21. Mohan S, Patel H, Bolinaga J, Soekamto N, Achu L, Teklemariam K: Dihydrobiopterin (BH2): Key determinant in influcencing arginien mediated endothelial tolerance and dysfunction. Am J Biochem Biotechnol 2012, 8:54-62

22. Hardie DG, Carling D: The AMP-activated protein kinase-fuel gauge of the mammalian cell? European journal of biochemistry/FEBS 1997, 246:259-273.

23. Winder WW: Energy-sensing and signaling by AMP-activated protein kinase in skeletal muscle. J Appl Physiol 2001, 91:1017-1028.

24. Reihill JA, Ewart MA, Hardie DG, Salt IP: AMP-activated protein kinase mediates VEGF-stimulated endothelial NO production. Biochem Biophys Res Commun 2007, 354:1084-1088.

25. Fisslthaler B, Fleming I, Keseru B, Walsh K, Busse R: Fluid shear stress and NO decrease the activity of the hydroxy-methylglutaryl coenzyme $A$ reductase in endothelial cells via the AMP-activated protein kinase and FoxO1. Circ Res 2007, 100:e12-21.

26. Chen $H$, Levine YC, Golan DE, Michel T, Lin AJ: Atrial natriuretic peptideinitiated cGMP pathways regulate vasodilator-stimulated phosphoprotein phosphorylation and angiogenesis in vascular endothelium. J Biol Chem 2008, 283:4439-4447.

27. Lowry OH, Rosebrough NJ, Farr AL, Randall RJ: Protein measurement with the Folin phenol reagent. J Biol Chem 1951, 193:265-275.

28. Xia Y, Zweier JL: Superoxide and peroxynitrite generation from inducible nitric oxide synthase in macrophages. Proc Natl Acad Sci U S A 1997, 94:6954-6958

29. Setsukinai K, Urano Y, Kakinuma K, Majima HJ, Nagano T: Development of novel fluorescence probes that can reliably detect reactive oxygen species and distinguish specific species. J Biol Chem 2003, 278:3170-3175.

30. Shin S, Fung SM, Mohan S, Fung HL: Simultaneous bioanalysis of L-arginine, L-citrulline, and dimethylarginines by LC-MS/MS. J Chromatogr B Analyt Technol Biomed Life Sci 2011, 879:467-474.

31. Forstermann $U$, Munzel T: Endothelial nitric oxide synthase in vascular disease: from marvel to menace. Circulation 2006, 113:1708-1714.

32. Zhang J, Xie Z, Dong Y, Wang S, Liu C, Zou MH: Identification of nitric oxide as an endogenous activator of the AMP-activated protein kinase in vascular endothelial cells. J Biol Chem 2008, 283:27452-27461.

33. Mount PF, Lane N, Venkatesan S, Steinberg GR, Fraser SA, Kemp BE, Power DA: Bradykinin stimulates endothelial cell fatty acid oxidation by CaMKKdependent activation of AMPK. Atherosclerosis 2008, 200:28-36.

34. Stahmann N, Woods A, Carling D, Heller R: Thrombin activates AMPactivated protein kinase in endothelial cells via a pathway involving Ca2+/calmodulin-dependent protein kinase kinase beta. Mol Cell Biol 2006, 26:5933-5945.

35. Wohlfart P, Malinski T, Ruetten H, Schindler U, Linz W, Schoenafinger $K$, Strobel H, Wiemer $G$ : Release of nitric oxide from endothelial cells stimulated by YC-1, an activator of soluble guanylyl cyclase. $\mathrm{Br} J$ Pharmacol 1999, 128:1316-1322.

36. Hwang TL, Hung HW, Kao SH, Teng CM, Wu CC, Cheng SJ: Soluble guanylyl cyclase activator YC-1 inhibits human neutrophil functions through a cGMP-independent but CAMP-dependent pathway. Mol Pharmacol 2003, 64:1419-1427.

37. Weber M, Lauer N, Mulsch A, Kojda G: The effect of peroxynitrite on the catalytic activity of soluble guanylyl cyclase. Free Radic Biol Med 2001, 31:1360-1367.

38. Munzel T, Daiber A, Mulsch A: Explaining the phenomenon of nitrate tolerance. Circ Res 2005, 97:618-628.

39. Stasch JP, Schmidt PM, Nedvetsky PI, Nedvetskaya TY HSA, Meurer S, Deile M, Taye A, Knorr A, Lapp H, et al: Targeting the heme-oxidized nitric oxide receptor for selective vasodilatation of diseased blood vessels. J Clin Investig 2006, 116:2552-2561

40. Stevanovic ID, Jovanovic MD, Jelenkovic A, Colic M, Stojanovic I, Ninkovic M: Effects of L-NAME, a non-specific nitric oxide synthase inhibitor, on AlCl3-induced toxicity in the rat forebrain cortex. J Vet Sci 2009, 10:15-22.

41. Xia $Y, T$ sai $A L$, Berka $V$, Zweier JL: Superoxide generation from endothelial nitric-oxide synthase. A Ca2+/calmodulin-dependent and tetrahydrobiopterin regulatory process. J Biol Chem 1998, 273:25804-25808.

42. Vasquez-Vivar J, Kalyanaraman B, Martasek P, Hogg N, Masters BS, Karoui H, Tordo P, Pritchard KA Jr: Superoxide generation by endothelial nitric oxide synthase: the influence of cofactors. Proc Natl Acad Sci U S A 1998, 95:9220-9225

43. Granner D, Pilkis S: The genes of hepatic glucose metabolism. J Biol Chem 1990, 265:10173-10176.

44. Pilkis SJ, Granner DK: Molecular physiology of the regulation of hepatic gluconeogenesis and glycolysis. Annu Rev Physiol 1992, 54:885-909.

45. Gitzelmann R: Galactose-1-phosphate in the pathophysiology of galactosemia. Eur J Pediatr 1995, 154:S45-49.

46. Gitzelmann R, Bosshard NU: Partial deficiency of galactose-1-phosphate uridyltransferase. Eur J Pediatr 1995, 154:S40-44.

47. Hanbauer I, Wink D, Osawa Y, Edelman GM, Gally JA: Role of nitric oxide in NMDA-evoked release of [3H]-dopamine from striatal slices. Neuroreport 1992, 3:409-412.

48. Kiedrowski L, Costa E, Wroblewski JT: Sodium nitroprusside inhibits $\mathrm{N}$-methyl-D-aspartate-evoked calcium influx via a nitric oxide- and cGMP-independent mechanism. Mol Pharmacol 1992, 41:779-784.

49. Mohan S, Fung HL: Mechanism of cellular oxidation stress induced by asymmetric dimethylarginine. Int J Mol Sci 2012, 13:7521-7531.

50. Mohan S, Wu CC, Shin S, Fung HL: Continuous exposure to L-arginine induces oxidative stress and physiological tolerance in cultured human endothelial cells. Amino Acids 2012, 43:1179-1188.

doi:10.1186/1743-7075-10-40

Cite this article as: Mohan et al:: AMP-activated protein kinase regulates L-arginine mediated cellular responses. Nutrition \& Metabolism 2013 $10: 40$.

\section{Submit your next manuscript to BioMed Central and take full advantage of:}

- Convenient online submission

- Thorough peer review

- No space constraints or color figure charges

- Immediate publication on acceptance

- Inclusion in PubMed, CAS, Scopus and Google Scholar

- Research which is freely available for redistribution 